- FINANSE I PRAWO FINANSOWE •

- Journal of Finance and Financial Law

Grudzień/December 2020 • vol. 4(28): 101-112

http://dx.doi.org/10.18778/2391-6478.4.28.06

\title{
DYREKTYWA O KREDYCIE KONSUMENCKIM \\ - UWAGI DE LEGE FERENDA
}

mgr Piotr Gałązka

Doktorant na WPAiE Uniwersytetu Wrocławskiego absolwent WPiA Uniwersytetu Warszawskiego oraz University of Cambridge and University of Warsaw British Law Centre, adwokat, członek Izby Adwokackiej w Warszawie, dyrektor Przedstawicielstwa Zwi zku Bank w Polskich w Brukseli

ORCID: https://orcid.org/0000-0002-7945-8422

\section{Streszczenie}

Celem artykułu jest om wienie Dyrektywy o kredycie konsumenckim oraz dokonanie oceny najważniejszych postulat w zmian w przepisach Dyrektywy w sytuacji dynamicznych zmian na rynku kredyt $w$ detalicznych. Podstawę rozważań artykułu stanowią uwagi i opinie przedstawicieli doktryny, zestawione z postulatami organizacji konsumenckich, nadzorc w, a także analizami prowadzonymi przez Komisję Europejską jako instytucji wyposażonej w prawo inicjatywy ustawodawczej W UE.

Słowa kluczowe: kredyt konsumencki, usługi finansowe, Unia Europejska, odpowiedzialne pożyczanie.

JEL Class: G51, G40, G23, G21, K22. 


\section{WSTĘP}

Dyrektywa o kredycie konsumenckim [Dyrektywa Parlamentu Europejskiego i Rady 2008/48/WE z dnia 23 kwietnia 2008 r. w sprawie umów o kredyt konsumencki oraz uchylająca dyrektywę Rady 87/102/EWG, Dz. Urz. UE L nr 133 z 22 maja 2008 r., s. 66-92] ${ }^{1}$ stanowiła znaczący krok w zakresie harmonizacji przepisów Unii Europejskiej odnośnie przepisów dotyczących kredytów konsumenckich. Rozwój tego rynku przy jednoczesnym zapewnieniu odpowiedniego poziomu pewności prawnej, informacji przedkontraktowej i gwarancji praw pożyczkobiorców wymagał opracowania przepisów na poziomie wyższym niż krajowy, również ze względu na umożliwienie budowania rynku transgranicznego w ramach jednolitego rynku w Unii Europejskiej.

Chociaż przepisy Dyrektywy przez dwanaście lat funkcjonowania były zmieniane w sposób nieznaczny [Nieoficjalny tekst jednolity Dyrektywy z listą zmian i źródeł zmian: https://eur-lex.europa.eu/legal-content/PL/TXT/PDF/?uri=CELEX:02008L0048-20190726\&from=EN, dostęp 30.05.2020], po wejściu w życie Dyrektywy doszło do kryzysu finansowego, który spowodował istotne zmiany o charakterze ekonomiczno-społecznym skutkujące wzrostem stopy bezrobocia w wielu państwach członkowskich [Eurostat, 2019, dostęp 16.06.2020] i spadkiem dochodów gospodarstw domowych w niektórych z państw. Gospodarka europejska po raz pierwszy zetknęła się z fenomenem niskich stóp procentowych, co skutkowało obniżeniem oprocentowania kredytów - wraz ze spadkiem dochodów konstytuowało istotną zachętę do zaciągania kredytów konsumenckich. Jednoczesna cyfryzacja detalicznych usług finansowych sprawiła, że dostępność kredytu znacząco wzrosła poprzez kanały obsługi klientów online.

Punktem wyjścia i hipotezą niniejszego opracowania jest założenie, że mimo iż przepisy Dyrektywy prima facie spełniają swoją rolę, ich funkcjonowanie na rynku kredytów w Unii Europejskiego wymaga oceny pod kątem odpowiedniości wobec potrzeb zmieniającego się rynku kredytów konsumenckich oraz oczekiwań potencjalnych kredytobiorców. Celem niniejszego artykułu będzie przedstawienie pokrótce ewolucji przepisów prawa Unii Europejskiej w zakresie regulacji kredytu konsumenckiego oraz ocena wybranych - z uwagi na brak nieograniczonego miejsca - oraz najistotniejszych postulatów odnośnie nowelizacji przepisów Dyrektywy, w oparciu o prawno-dogmatyczną metodę badawczą, a także posiłkując się metodą teoretyczno-prawną - mając na uwadze oceny prezentowane przez przedstawicieli doktryny oraz metodą historyczną, w odniesieniu do zmian w legislacji unijnej dotyczącej ochrony kredytobiorcy jako konsumenta.

\footnotetext{
${ }^{1}$ Zwana dalej w artykule „Dyrektywą”.
} 


\section{PRZEPISY OBOWIAZZUJĄCE PRZED WEJŚCIEM W ŻYCIE DYREKTYWY}

Przepisy Dyrektywy stanowiły drugą tego typu regulację na poziomie unijnym, po Dyrektywie Rady uchwalonej pod koniec 1986 r. [Dyrektywa Rady 87/102/EWG...: 48-53]. Jej celem było ograniczenie różnic w przepisach między państwami członkowskimi w tej dziedzinie w celu ochrony rynku wewnętrznego ${ }^{2}$. Wskazuje to wyraźnie, że ochrona konsumenta zalicza się do kompetencji Wspólnot Europejskich i Unii Europejskiej jako element dbania o urzeczywistniania jednolitego rynku europejskiego [Por. Nadolska 2019: 57 i nast.].

Dyrektywa z 1986 roku miała na celu określenie jednolitych zasad odnośnie informacji, które konsument powinien uzyskać o warunkach i kosztach kredytu. Zaznaczono, że informacja ta winna zawierać między innymi roczną stopę oprocentowania kredytu lub, jeśli takiej informacji zabraknie, całkowitą kwotę, jaką konsument ma zapłacić za kredyt ${ }^{3}$. Przewidywano także obowiązki informacyjne w odniesieniu do ogłoszeń i reklam kredytu, a także wprowadzano obowiązkowe elementy umowy o kredyt konsumencki.

\section{ZAŁOŻENIA PRZY PRACACH LEGISLACYJNYCH NAD DYREKTYWA}

\subsection{Projekt legislacyjny}

Pierwszy projekt Dyrektywy Komisji Europejskiej [Komisja Europejska 2002b, dostęp 27.06.2020] zawierał uzasadnienie, iż dotychczasowe unijne przepisy z 1986 roku nie nadążają za ewolucją funkcjonowania rynku kredytowego, co skutkowało powstaniem wielu przepisów uzupełniających na poziomie krajowym. Projekt już w swojej pierwotnej wersji z 2002 roku zawierał wiele założeń [Komisja Europejska 2002a: art. 2 lit. h), i) oraz j): 226] dotyczących zwiększenia zakresu informacji i transparentności wobec kredytobiorcy, których znaczenie wzrosło znacząco po kryzysie finansowym w 2008 roku, gdy nastąpiła zmiana paradygmatu ochrony konsumenta [Monkiewicz i Monkiewicz 2005: 5]. Przede wszystkim przewidywał wyższy poziom harmonizacji i zakaz wprowadzania dodatkowych przepisów przez Państwa członkowskie. Novum było wprowadzenie możliwości odstąpienia przez konsumenta od umowy kredytu w terminie 14 dni od jej zawarcia.

\footnotetext{
${ }^{2}$ Por. Preambuła Dyrektywy 87/102/EWG: 48.

${ }^{3}$ Preambuła, op. cit.
} 


\subsection{Przebieg procesu legislacyjnego}

W toku procesu legislacyjnego Komisja zmieniała projekt [Komisja Europejska 2004; Komisja Europejska 2005]. Doprecyzowano obowiązki kredytodawcy w zakresie doradztwa na rzecz kredytobiorcy, czyli wyjaśniono przepisy, które konstytuują obowiązek odpowiedzialnego udzielania kredytów (responsible lending) [Komisja Europejska 2005: 7]; odszedłszy od założenia maksymalnej harmonizacji, uznano na zasadzie pomocniczości i proporcjonalności, że harmonizacja $\mathrm{z}$ pozostawieniem państwom członkowskim elastyczności w niektórych obszarach z zastosowaniem zasady wzajemnego uznawania, będzie efektywnym rozwiązaniem, nie stanowiącym przeszkody dla rozwoju rynku wewnętrznego w sektorze kredytów konsumenckich [Komisja Europejska 2005: 8-9].

\section{POSTULATY ZMIAN PRZEPISÓW DYREKTYWY}

Zmiany na rynku detalicznych usług finansowych - w szczególności cyfryzacja usług finansowych, ewolucja praktyk rynkowych oraz nowe ramy prawne na poziomie Unii Europejskiej - spowodowały, że otoczenie rynkowe i regulacyjne udzielania kredytów konsumentom jest całkiem inne od tego, gdy procedowano projekt Dyrektywy [Gałązka 2019a, dostęp 29.05.2020]. Pojawiają się postulaty zmian w przepisach Dyrektywy. W ocenie Autora na uwagę w szczególności zasługuje kilka postulatów de lege ferenda przedstawionych poniżej.

\subsection{Zakres danych wykorzystywanych przy ocenie zdolności kredytowej}

Pierwszy postulat dotyczy sposobu prowadzenia oceny zdolności kredytowej kredytobiorcy. Artykuł 8 Dyrektywy stanowi, aby przy wdrażaniu przepisów Dyrektywy, określić obowiązek przeprowadzenia przez kredytodawcę „oceny zdolności kredytowej konsumenta na podstawie wystarczających informacji $[\ldots]$ oraz, $[\ldots]$ na postawie informacji uzyskanych z odpowiedniej bazy danych". Potwierdza to także Preambuła do Dyrektywy w motywie 26. Wynika to z zasady odpowiedzialnego udzielania kredytów (responsible lending) [Rutkowska i Paleczna 2018, 4244], która stanowiła podstawę aksjologiczną już pierwotnego projektu Dyrektywy, lecz znaczenie właściwego projektowania produktu finansowego, zwłaszcza o charakterze kredytowym z punktu widzenia ochrony konsumenta stało się zdecydowanie bardziej dostrzeżone w czasach po kryzysie finansowym z $2008 \mathrm{r}$. [EBA 2016, dostęp 28.06.2020].

Dobrym przykładem pokazującym różnice w podejściu prawodawcy unijnego do tego zagadnienia może być porównanie szczegółowości przepisów odnoszących się do obowiązku badania zdolności kredytowej między Dyrektywą 
a dyrektywą o kredycie hipotecznym [Dyrektywa Parlamentu Europejskiego i Rady 2014/17/UE...]. Ta druga regulacja unijna, zaprojektowana została już po kryzysie finansowym, podczas gdy tę pierwszą zaprojektowano długo przed nim, gdy istniało przekonanie o racjonalności i efektywności rynku finansowego, którego funkcjonowanie wymaga jedynie dostępności do informacji [Cyman 2016: 39]. Dlatego też nie poprzestaje ona wyłącznie na założeniu słuszności działania instytucji finansowych i przepisach ramowych jak w Dyrektywie, lecz kwestię badania zdolności kredytowej reguluje bardzo dokładnie poświęcając jej nie przepis, lecz dwa rozdziały, jeśli weźmiemy pod uwagę także ten o dostępie do baz danych.

Koncepcja odpowiedzialnego pożyczania opiera się na założeniu, że pożyczkodawca nie powinien działać tylko we własnym interesie, lecz także brać pod uwage potrzeby i interesy pożyczkobiorcy podczas trwania całości relacji umownej, aby nie prowadzać do sytuacji dla konsumenta niekorzystnej na wielu płaszczyznach, gdy jego zadłużenie osiągnie wysokość zagrażającą utrzymaniu zrównoważonego budżetu domowego [Financial Services User Group 2019: 6]. Jednym z trzech elementów odpowiedzialnego pożyczania, oprócz obowiązku przeprowadzenia oceny odpowiedniości (suitability) danego produktu dla danego konsumenta oraz obowiązku uczciwego traktowania pożyczkobiorcy w sytuacji trudności spłaty kredytu, jest obowiązek oceny zdolności kredytowej [European Coalition for Responsible Credit, dostęp 28.06.2020]. Doktryna prawa ochrony konsumenta usług finansowych podnosi, że postulowanym działaniem kredytodawcy jest badanie nie tylko tego, czy dany konsument jest w stanie spłacić w całości kredyt wraz z odsetkami i opłatami, lecz także czy może tego dokonać bez istotnego pogorszenia swojej sytuacji finansowej [Ramsay 2016: 159].

Model oceny zdolności kredytowej określony w Dyrektywie jest oparty wyłącznie na ochronie interesów kredytodawcy, jako że skupia się na badaniu możliwości spłaty kredytu - nie wymaga wprost badania zgodności z interesami konsumenta [Fairweather 2012: 94-95]. W doktrynie zwraca się także uwagę, że w Dyrektywie - przy ogólnych przepisach dotyczących zbierania danych i ich oceny w celu zbadania zdolności kredytowej - brakuje trzeciego istotnego elementu sankcjonującego obowiązek odpowiedzialnego pożyczania, tj. określenia skutków, jakie wywołuje działanie niezgodne $\mathrm{z}$ wynikiem badania zdolności [Howells i in. 2017: 281]. Brak jest przepisu wprost zakazującego udzielenia kredytu konsumentowi, który nie posiada zdolności kredytowej w oparciu o pewne i potwierdzone dane. Postulat ten ocenić należy za istotny mając na uwadze potrzebę zapewnienia jednolitego poziomu ochrony konsumenta w poszczególnych państwach członkowskich, a w konsekwencji uzyskania punktu odniesienia w tym zakresie. 


\subsubsection{ODMIENNE ZAKRESY DANYCH W POSZCZEGÓLNYCH PAŃSTWACH CZŁONKOWSKICH}

Ze względu na fakt, że Dyrektywa nie zapewnia państwom członkowskich wystarczających wskazówek, zakres danych wymaganych przez przepisy krajowe różni się w poszczególnych państwach członkowskich [Komisja Europejska 2018: 5]. W zakresie regulacji co do danych żądanych od wnioskujących o kredyt, podejście państw bywa bardzo rozbieżne [Komisja Europejska 2018: 6-8].

Jak Dyrektywa stanowi o obowiązku badania zdolności kredytowej, tak jednocześnie jej przepisy nie normują sposobu przeprowadzenia zdolności kredytowej, posługując się jedynie klauzulą generalną „,wystarczających informacji”. Brak przepisów Dyrektywy odnoszących się wprost do zakresu choćby minimalnego danych, które powinny być żądane od kredytobiorcy bądź określenie poziomów progowych kwotowych, w przypadku których kredytodawca powinien żądać dodatkowych informacji, potwierdzenia lub uwiarygodnienia przedstawionych danych, może prowadzić do niewłaściwego lub niewystarczającego badania zdolności kredytowej, naruszając tym samym zasadę odpowiedzialnego pożyczania.

\subsubsection{OGRANICZENIE ROZWOJU RYNKU WEWNĘTRZNEGO}

Kwestia odmiennych standardów i definicji „wystarczających informacji” stanowi znaczące utrudnienie przy rozwoju transgranicznych kredytów konsumenckich w Unii Europejskiej i uniemożliwia urzeczywistnienie rynku wewnętrznego w tym zakresie. Uwagę na to zwróciła także Komisja Europejska, uznając że „oceny [zdolności kredytowej] w obszarze kredytów konsumenckich są przeprowadzane na bardzo różne sposoby w poszczególnych państwach członkowskich" i prowadzi do sytuacji braku „ustandaryzowanej i ujednoliconej oceny zdolności kredytowej" [Komisja Europejska 2017: 12]. Brak jednolitych standardów rodzi dużą barierę wejścia na nowe rynki, co powoduje, że mniej rozwinięte rynki usług finansowych będą pozostawały nadal defaworyzowane, a dostępność kredytu dla konsumenta w tych państwach nie będzie rosła [Gałązka 2019b: 98].

\subsection{Ochrona konsumenta przy cyfrowych kanałach zdalnej sprzedaży kredytu}

Istotnym wyzwaniem na rynku kredytów konsumenckich jest kwestia odpowiedniego uwzględnienia w przepisach Dyrektywy nowych form udzielania kredytów za pomocą kanałów elektronicznych. Dygitalizacja obrotu gospodarczego i usług finansowych, postępuje w szybkim tempie, powodując że elektroniczna obsługa klienta stała się podstawową formą działania dla wielu instytucji finansowych. 
Powstało wiele nowych modeli biznesowych opartych wyłącznie na komunikacji zdalnej z klientem, bez możliwości kontaktu osobistego.

Za mocną stronę Dyrektywy uznać należy szeroką definicję kredytu konsumenckiego, która w założeniu miała być pojemna i funkcjonalna jako pojęcie, które będzie przyszłościowe i otwarte na innowacje na rynku kredytów konsumenckich [Howells i in. 2017: 259]. Niemniej jednak brak w Dyrektywie przepisów odnoszących się do umów zawieranych za pomocą środków komunikacji elektronicznej, gwarantujących odpowiedni poziom informacji dla konsumenta, może naruszać faktyczne jego prawa, podczas gdy zapewnienie odpowiedniego poziomu zrozumiałych dla konsumenta informacji stało się jedną z najważniejszych gwarancji ochrony praw konsumenta usług finansowych [Rutkowska 2013: 326]. Realizacja tego postulatu jest istotna w sytuacji, gdy dotychczas obowiązujące przepisy zdają się nie sprostać wymogom nowych modeli biznesowych na rynku, choć nie oznacza to, że wymagane jest tworzenie przepisów szczególnych dla poszczególnych kanałów komunikacji z kredytobiorcą, jeśli przepisy ogólne spełnią swoją rolę w tym zakresie.

\subsubsection{MOŻLIWOŚĆ PORÓWNANIA OFERT PRZEZ KONSUMENTA}

Pomimo istnienia europejskich przepisów dotyczących zawierania konsumenckich umów usług finansowych na odległość [Dyrektywa Parlamentu Europejskiego i Rady 2002/65/WE...: 16-24], brak jest przepisów odnoszących się bezpośrednio do transakcji w internecie oraz dotyczących wyłącznie produktów kredytowych.

Oczywiście kanały online to korzyści dla konsumentów w postaci łatwiejszej i większej dostępności kredytu, dostępność środków praktycznie niezwłocznie po zawarciu umowy kredytu, a także przeciwdziałanie wykluczeniu finansowemu [Ayoub i Bouyon 2018: 3]. Zagadnienie wiąże się jednak również z zagrożeniami $\mathrm{w}$ stosunku do realizacji $\mathrm{w}$ praktyce zasady odpowiedzialnego pożyczania poprzez uniemożliwienie konsumentowi zapoznania się ze wszystkimi niezbędnymi informacjami „w stosownym czasie przed związaniem się [...] umową"4 i porównania ofert. Wysoka dostępność tego typu kredytów bywa kusząca i wymaga od prawodawcy opracowania ram regulacyjnych, które będą egzekwowały odpowiedzialne działania kredytodawców prowadzących często agresywny i niechciany marketing tego typu usług kredytowych. Warto zwrócić uwagę, że dostępność środków praktycznie w czasie rzeczywistym może skutkować pozbawieniem w praktyce konsumenta prawa do odstąpienia od umowy, który łatwo dostępne środki równie łatwo wyda, nie mogąc ich zwrócić w terminie zakreślonym w art. 14 ust. 3 lit. b) Dyrektywy. Ponadto, łatwa i niezwłoczna dostępność

\footnotetext{
${ }^{4}$ Vide art. 5 Dyrektywy.
} 
środków może powodować zbyt wysokie zadłużenie konsumenta, któremu odpowiedzialny kredytodawca powinien przeciwdziałać. Rozważyć zatem należy wprowadzenie przepisów opóźniających wypłatę kredytu o określony termin, z którego konsument może zrezygnować składając deklarację na osobnym niż sama umowa dokumencie, zawierającym odpowiednie pouczenia.

\subsubsection{PRZEJRZYSTOŚĆ INFORMACJI O KREDYCIE ON-LINE}

W kontekście kredytów konsumenckich oferowanych online, pojawia się także zagadnienie jasności i przejrzystości informacji przedstawianych przez kredytodawcę konsumentowi. W sytuacji, gdy kredyt udzielany jest za pomocą aplikacji na telefon komórkowy bądź innym urządzeniu mobilnym, możliwość zrozumienia informacji wymaganej art. 5 Dyrektywy jest zdecydowanie trudniejsza [Komisja Europejska 2020: 1].

Rozważyć należy zatem uproszczenie wzorca europejskiego arkusza informacyjnego dotyczącego kredytu konsumenckiego, tak by był on łatwiejszy w odbiorze, zwłaszcza przy zawieraniu umowy online - choćby poprzez wykorzystanie ustandaryzowanych znaków graficznych, podobnie jak ma to miejsce w przypadku informacji zgodnie z przepisami PRIIPs [Gałązka 2019c: 271].

\subsection{Zjawisko niechcianego kredytu przy sprzedaży kredytu konsumenckiego}

Zagadnienie niechcianych ofert dotyczących produktów kredytowych istnieje w praktyce rynkowej w wielu formach. Co do zasady tego typu działania kredytodawców prowadzą do sytuacji, w której konsumenci zadłużają się w większym stopniu. Istnieje ryzyko, że decyzje o zwiększaniu zadłużenia bądź zaciąganiu dodatkowych zobowiązań w ramach nowych umów kredytowych nie wynikają z faktycznych potrzeb konsumentów, lecz są skutkiem namów i zachęt ze strony kredytodawców. To może powodować wzrost poziomu zadłużenia przekraczający próg możliwości jego obsługi przez konsumenta - jeśli tego typu działanie jest skutkiem działań kredytodawcy, jest to niezgodne z zasadą odpowiedzialnego pożyczania [Financial Services User Group 2019: 10]. Badania w jednym z państw wykazały, że w ciągu 12 miesięcy do listopada 2017 roku $28 \%$ posiadaczy kart kredytowych uzyskało podniesienie limitu kredytowego na karcie - istotniejsze jest jednak to, że jedynie jedna czwarta posiadaczy kart wnioskowała o to, pozostała część otrzymała tenże limit z inicjatywy wydawcy karty [Citizens Advice 2017, dostęp 30.06.2020]. Można z tego wywodzić, że dynamika zapotrzebowania na kredyt konsumencki jest niższe niż faktyczny wzrost wartości całości kredytów, który wynikać może z przyczyn leżących po stronie udzielających kredytów konsumenckich. 
Rozważyć zatem należy wprowadzenie przepisu, który będzie w większym stopniu - mając na uwadze zasadę odpowiedzialnego pożyczania - kładł nacisk na inicjatywę ze strony konsumenta w celu uzyskania kredytu konsumenckiego. Wspomniana wcześniej dyrektywa o sprzedaży usług finansowych na odległość zawiera przepisy, które odpowiednio regulują dane zagadnienie ${ }^{5}$ - rozważyć należy wprowadzenie analogicznych przepisów w Dyrektywie, zwłaszcza że poszczególne państwa członkowskie podjęły odpowiednie inicjatywy w tym zakre$s^{6}{ }^{6}$. Postulatu tego jednak nie można identyfikować opacznie - nie można uznać, że jakakolwiek inicjatywa ze strony kredytodawcy mająca na celu przedstawienie oferty kredytowej musi być oceniana negatywnie. Głównym postulatem pozostaje tutaj nadal zapewnienie konsumentowi takiego zakresu informacji, by jego decyzja o zainicjowaniu procesu w celu uzyskania kredytu była świadoma i niewymuszona [Szpunar 2019: pkt 1 in fine].

\section{PODSUMOWANIE}

Ocena funkcjonowania przepisów Dyrektywy pozostaje wysoka. Jej obowiązywanie pozwoliło konsumentom na większą pewność przy zawieraniu umów kredytowych, dzięki takim uprawnieniom jak prawo do odstąpienia od umowy kredytowej w terminie 14 dni od jej zawarcia, a prawo do wcześniejszej spłaty kredytu pozwoliło ograniczyć ryzyko nadmiernego zadłużania się konsumentów. W zakresie obowiązków nałożonych na kredytodawców, godnym pochwały jest oparcie aksjologiczne przepisów Dyrektywy na zasadzie odpowiedzialnego pożyczania, która materializuje się w przepisach odnoszących się do badania zdolności kredytowej jako przesłanki udzielenia kredytu.

Niemniej jednak zmiany ewoluujące na rynku kredytów konsumenckich powodują, że przepisy Dyrektywy wymagają powtórnej analizy w celu zbadania, czy spełniają swoją rolę w zakresie ochrony konsumenta kredytowych usług finansowych. W świetle przedstawionych rozważań, najważniejszą kwestią pozostaje badanie, czy w zmieniającej się rzeczywistości rynku kredytów konsumenckich, konsument jest faktycznie i materialnie, a nie tylko formalne, poinformowany o ofercie przedstawianej mu przez danego kredytodawcę oraz odnośnie swoich praw i obowiązków wynikających z podjęcia decyzji o zaciągnięciu kredytu. Istotne jest to, aby jego osąd i ocena oferty była możliwie jak najpełniejsza i odbywała się w korzystnych warunkach, bez nacisku na decyzję o zawarcie umowy. Ponadto, potrzeba jest zastanowienia, czy po kilkunastu latach aktywnej

\footnotetext{
${ }^{5}$ Vide art. 9 i 10 Dyrektywy 2002/65/WE.

${ }^{6}$ Por.: rozwiązania irlandzkie - wymóg zgody konsumenta na podniesienie limitu kredytowego karty kredytowej [Central Bank of Ireland 2012: pkt. 3.15, s.11, dostęp 30.06.2020].
} 
polityki Unii Europejskiej w zakresie ochrony konsumenta, przepisy Dyrektywy są nadal spójne z innymi przepisami prawa UE.

Oprócz kwestii zabezpieczenia i właściwego stosowania w praktyce środków ochrony konsumenta usług finansowych o charakterze kredytowym, należy także mieć na uwadze zagadnienie dostępności i kosztów kredytu. Zbyt rozbudowane, nieproporcjonalne obowiązki nakładane na kredytodawców konsumenckich będą prowadzily do braku zainteresowania tym rynkiem. Obniżenie konkurencyjności nie będzie czynnikiem sprzyjającym wzrostowi ochrony konsumenta i obniżeniu kosztów kredytu. Dlatego za szczególnie ważne uznać należy postulaty dotyczące zapewnienia harmonizacji poziomu ochrony konsumenta z jednej strony poprzez uszczegółowienie przepisów w zakresie oceny zdolności kredytowej, a z drugiej poprzez zapewnienie konsumentowi na etapie przedkontraktowym i przy zawieraniu umowy odpowiedniego wysokiego poziomu informacji i świadomości na temat zakresu obowiązków wynikających z zawieranej umowy kredytu konsumenckiego. To drugie winno być zapewnione w sposób nie budzący wątpliwości w każdym z kanałów komunikacji z konsumentem.

\section{BIBLIOGRAFIA}

Ayoub J., Bouyon S., 2018, Consumer Credit, Digitalisation and Behavioural Economics. Are new protection rules needed?, „ECRI Policy Brief”, no. 9, September.

Central Bank of Ireland 2012, Consumer Protection Code 2012, pkt. 3.15, s. 11, https://www.centralbank.ie/docs/default-source/regulation/consumer-protection/other-codes-of-conduct/4gns-4-2-7-cp-code-2012.pdf?sfvrsn=6 [dostęp 30.06.2020].

Citizens Advice 2017, Credit card companies pushing credit on millions of people who can't pay, 17 listopada 2017 r., https://www.citizensadvice.org.uk/about-us/how-citizens-adviceworks/media/press-releases/credit-card-companies-pushing-credit-on-millions-of-peoplewho-cant-pay/ [dostęp 30.06.2020].

Cyman D., 2016, Kierunki zmian ochrony konsumenta uslug finansowych w Unii Europejskiej, „Annales Universitatis Mariae Curie-Skłodowska - Sectio H", vol. 50, no. 4.

European Coalition for Responsible Credit, Principles of Responsible Credit, https://www.responsible-credit.net/media.php?id=1651 [dostęp 28.06.2020].

EBA (Europejski Urząd ds. Nadzoru Bankowego), 2016, Wytyczne dotyczace zasad nadzoru nad produktami i ustaleń zarzadczych dla produktów bankowości detalicznej, EBA/GL/2015/18, 22 marca $2016 \quad$ r., https://eba.europa.eu/sites/default/documents/files/documents/10180/1412678/b0bf150d-2f9d-4c52-ab45-5738e2e380be/EBA-GL-2015-18\%20Guidelines\%20on\%20product\%20oversight\%20and\%20Governance_PL.pdf [dostęp 28.06.2020].

Eurostat, 2019, Dane statystyczne dotyczace zatrudnienia, dane z maja 2019 r., https://ec.europa.eu/eurostat/statistics-explained/index.php?title=Employment_statistics/pl\&oldid=359045 [dostęp 16.06.2020].

Fairweather K., 2012, The development of responsible lending in the UK, [w:] J. Devenney, M. Kenny (red.), Consumer Credit, Debt and Investment in Europe, Cambridge University Press.

Financial Services User Group Komisji Europejskiej, 2019, FSUG opinion and recommendations for the review of the Consumer Credit Directive, 8 kwietnia 2019 r., s. 6 , 
https://ec.europa.eu/info/sites/info/files/business_economy_euro/banking_and_finance/documents/fsug-opinions-190408-responsible-consumer-credit-lending_en.pdf [dostęp 28.06.2020].

Gałązka P., 2019a, Dyrektywa o kredycie konsumenckim - konsultacje rozpoczęte, 21.01.2019 r., AleBank.pl, https://alebank.pl/dyrektywa-o-kredycie-konsumenckim-konsultacje-rozpoczete/ [dostęp 29.05.2020].

Gałązka P., 2019b, Różnice w ocenie zdolności kredytowej konsumenta w państwach członkowskich UE jako ograniczenie jednolitego rynku kredytów - analiza w kontekście zasady minimalizacji danych z art. 5 RODO, ,internetowy Kwartalnik Antymonopolowy i Regulacyjny”, nr 8.

Gałązka P., 2019c, Obowiązi informacyjne dostawców uslug finansowych wedlug rozporządzenia PRIIP, [w:] E. Rutkowska-Tomaszewska, Informacja na rynku ustug finansowych, PWE, Warszawa.

Howells G., Twigg-Flesner Ch., Wilhelmsson T., 2017, Rethinking UE Consumer Law, Markets and the Law, City University of Hong Kong, Routledge.

Komisja Europejska 2002a, Proposal for a Directive of the European Parliament and of the Council on the harmonisation of the laws, regulations and administrative provisions of the Member States concerning credit for consumers, COM/2002/0443 final - COD 2002/0222, Dz.Urz. UE E nr 331 z 31.12.2002.

Komisja Europejska 2002b, Nota prasowa „Consumer credit rules for the 21st century”, IP/02/1289, 11 września 2002, https://ec.europa.eu/commission/presscorner/detail/en/IP_02_1289 [dostęp 27.06.2020].

Komisja Europejska 2004, Zmieniony wniosek dotyczący Dyrektywy Parlamentu Europejskiego i Rady w sprawie harmonizacji przepisów ustawowych, wykonawczych i administracyjnych Państw Członkowskich dotyczących kredytu konsumenckiego znoszącej dyrektywę 87/102/WE i zmieniającej dyrektywę 93/13/WE przedstawiona przez Komisję na mocy art. 250 ust. 2 Traktatu WE, COM(2004)747 końcowy, 2002/0222 (COD), 28 października 2004 r.

Komisja Europejska 2005, Zmieniony wniosek Dyrektywa Parlamentu Europejskiego i Rady w sprawie umów o kredyt konsumencki, zmieniająca dyrektywę Rady 93/13/WE, przedstawiony przez Komisję na mocy art. 250 ust. 2 Traktatu WE, COM(2005) 483 końcowy/2, 2002/0222 (COD), 23 listopada 2005 r.

Komisja Europejska 2018, Mapping of national approaches in relation to creditworthiness assessment under Directive 2008/48/EC on credit agreements for consumers, Bruksela, marzec $2018 \mathrm{r}$.

Komisja Europejska 2017, Komunikat Komisji do Parlamentu Europejskiego, Rady, Europejskiego Banku Centralnego, Europejskiego Komitetu Ekonomiczno-Społecznego i Komitetu Regionów: Plan działania w sprawie detalicznych usług finansowych: szersza oferta i lepsze produkty, COM/2017/0139 final, Bruksela, marzec 2017 r.

Komisja Europejska 2020, Inception Impact Assessment - Review of the Consumer Credit Directive (2008/48/EC), Ref. Ares(2020)3256802, 23 czerwca 2020 r.

Monkiewicz J., Monkiewicz M., 2005, Tendencje rozwoju rozwoju ochrony konsumentów na rynku ubezpieczeniowym. Nowe koncepcje i rozwiazania, ,Rozprawy Ubezpieczeniowe”, nr 1, z. 18.

Nadolska A., 2019, Konsument $i$ klient na rynku ushug finansowych. Problem zakresu podmiotowego ochrony na rynku finansowym, [w:] J. Monkiewicz, E. Rutkowska-Tomaszewska (red.), Ochrona konsumenta na polskim i międzynarodowym rynku finansowym, Wolters Kluwer, Warszawa.

Ramsay I., 2016, Changing Policy Paradigms of EU Consumer Credit and Debt Regulation, [w:] D. Leczykiewicz, S. Weatherill (red.), The Images of the Consumer in EU Law: Legislation, Free Movement and Competition Law, Hart Publishing, Oxford.

Rutkowska-Tomaszewska E., Paleczna M., 2018, Idea odpowiedzialnego kredytowania na rynku niebankowych kredytów konsumenckich w Polsce, ,internetowy Kwartalnik Antymonopolowy i Regulacyjny", nr 6(7). 
Rutkowska-Tomaszewska E., 2013, Ochrona prawna klienta na rynku uslug bankowych, Wolters Kluwer, Warszawa.

Szpunar M., 2019, Opinia Rzecznika Generalnego w sprawie C-125/18 Marc Gómez del Moral Guasch przeciwko Bankia SA, 10 września 2019 r.

\title{
Źródla prawa :
}

Dyrektywa Parlamentu Europejskiego i Rady 2002/65/WE z dnia 23 września 2002 r. dotycząca sprzedaży konsumentom usług finansowych na odległość oraz zmieniająca dyrektywę Rady 90/619/EWG oraz dyrektywy 97/7/WE i 98/27/WE, Dz.Urz. UE L 271 z 9 października 2002 r.

Dyrektywa Parlamentu Europejskiego i Rady 2008/48/WE z dnia 23 kwietnia 2008 r. w sprawie umów o kredyt konsumencki oraz uchylająca dyrektywę Rady 87/102/EWG, Dz. Urz. UE L nr 133 z 22 maja 2008 r., s. 66-92.

Dyrektywa Parlamentu Europejskiego i Rady 2014/17/UE z dnia 4 lutego 2014 r. w sprawie konsumenckich umów o kredyt związanych z nieruchomościami mieszkalnymi i zmieniająca dyrektywy 2008/48/WE i 2013/36/UE oraz rozporządzenie (UE) nr 1093/2010, Dz. Urz. UE L 60 z 28 lutego $2014 \mathrm{r}$.

Dyrektywa Rady 87/102/EWG z dnia 22 grudnia 1986 r. w sprawie zbliżenia przepisów ustawowych, wykonawczych i administracyjnych Państw Członkowskich dotyczących kredytu konsumenckiego, Dz. Urz. UE L nr 42 z 12 lutego 1987 r., s. 48-53, polska wersja językowa: polskie wydanie specjalne: Rozdział 15 Tom 001, s. 326-331.

Dyrektywa Rady 90/88/EWG z z dnia 22 lutego 1990 r. zmieniająca dyrektywę 87/102/EWG w sprawie zbliżenia przepisów ustawowych, wykonawczych i administracyjnych Państw Członkowskich dotyczących kredytu konsumenckiego, Dz. Urz. UE L 061 z 10 marca 1990 r., s. 14-18.

\section{CONSUMER CREDIT DIRECTIVE - DE LEGE FERENDA REMARKS}

\begin{abstract}
The purpose of the article is to discuss the Consumer Credit Directive, as well as to make an assessment of the most important changes postulates of the Directive in the event of dynamic changes on the retail credit market. The article is based on the comments and opinions of the representatives of the doctrine, combined with the postulates of consumer organizations and supervisors, as well as analyses conducted by the European Commission as sole institution equipped with the legislative initiative in the EU.
\end{abstract}

Keywords: consumer credit, financial services, European Union, responsible lending. 